PRZEGLAॄD BIBLIOTECZNY 2019

e-ISSN 2545-2487

ELŻBIETA BARBARA ZYBERT

Faculty of Journalism, Information and Book Studies

University of Warsaw

e.zybert@uw.edu.pl

ORCID: 0000-0002-4959-8504

\title{
THE ROLE OF LIBRARIES, ARCHIVES AND MUSEUMS (LAM) IN THE PRESERVATION OF CULTURAL HERITAGE: THE EXAMPLE OF THE POLISH CATHOLIC CENTRE IN MARTIN CORONADO IN ARGENTINA
}

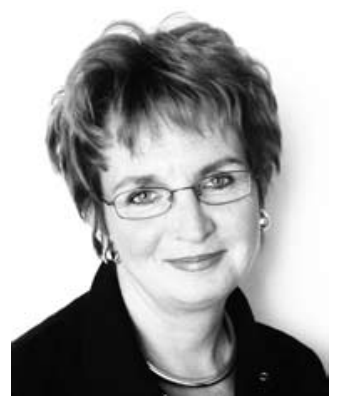

ELŻBIETA BARBARA ZYBERT is full professor at the Faculty of Journalism, Information and Book Studies (earlier Faculty of History), University of Warsaw, Poland. Her major academic work is devoted to contemporary librarianship, in particular to four areas: 1) library organization and management, 2) role and place of the library in education, 3) role of libraries in preserving Polish cultural heritage, 4) special groups of users (mentally retarded, disabled, prisoners, ethnic minorities, people experiencing homelessness, etc.). Her scholarly interests are reflected in her six books and in over 120 articles published in both Polish and foreign journals. Among others these include Biblioteki więzienne. Zarys problematyki (Prison libraries. An outline of problems, 1991); Kultura organizacyjna w bibliotekach (Organizational culture in libraries, 2004), Jakość w działalności bibliotek (Quality in library activities, 2007), ... do Polski idziemy przez caty świat..., Karpatczycy na obrazach Jana Gilowskiego (...We go to Poland through the world..., The Carpatians in the paintings of Jan Gilowski, 2018, in co-authorship with E. Maruszak). She has also edited several other books. Apart from her didactic and scholarly work professor Elżbieta Barbara Zybert is involved in a number of university activities; she is currently the Head of the Department for the Study of Libraries and Other Cultural Heritage Institutions. Earlier (2008-2016) she was Dean of the Faculty of History (in whose structure the Institute for Information and Book Studies operated until 2016), University 
of Warsaw, and was its Vice-Dean for student affairs (2005-2008). She is Editor-in-Chief of „Przegląd Biblioteczny” („Library Review”), the oldest Polish Research Journal in Library and Information Science. For over 20 years he has been managing the Postgraduate Studies in Librarianship.

KEYWORDS: Libraries, archive, museum (LAM). Polish Catholic Centre (Polski Ośrodek Katolicki - POK). Martin Coronado (Maciaszkowo). Polish cultural heritage. 2nd Polish Corps (2 Korpus Polski). 3rd Carpathian Rifle Division (3 Dywizja Strzelców Karpackich $-3 \mathrm{DSK})$

ABSTRACT. Objective - activities aiming at the preservation of the Polish cultural heritage undertaken by the library, archive, and museum functioning at the Polish Catholic Centre (Polski Ośrodek Katolicki-POK) in Martin Coronado in Argentina are presented. Particular attention is paid to the legacy of soldiers fighting on the fronts of World War II, mainly associated with the 2nd Polish Corps commanded by General Władysław Anders. Methods - A method of analysis and literary criticism was used. Results and conclusions - The Polish Catholic Centre in Martin Coronado and its libraries, archive, and museum are important in commemorating the contribution of Polish soldiers to the victory of World War II. They also play an important role in relation to the Polish community, affecting the state of national and social consciousness, shaping and maintaining its national identity, as well as strengthening patriotic attitudes.

Although an interest in artistic, historical, cultural, or natural goods as being important values for various social, ethnic, or national groups has appeared a long time ago, in the last few decades we can observe an everincreasing concern among entire societies as well as among the inhabitants of the entire globe towards their preservation and protection. These activities are also largely helped and supported by, among others, international conventions on the protection of world heritage, e.g. the UNESCO Convention of 1972 or the Council of Europe Framework Convention of 2005.

According to the Council of Europe Framework Convention on the Value of Cultural Heritage for Society, adopted in 2005 in Faro, Portugal, cultural heritage means a contemporary cultural heritage regarded as a group of resources "inherited from the past, which communities identify, independent of ownership, as a reflection and expression of their constantly evolving system of values, beliefs, knowledge and traditions" (Skaldawski, 2017b, p. 11). It may take the form of a material and immaterial legacy passed down by previous generations and defining our culture. The material heritage may be objects, artefacts, clothes, works of art, books, archives, machines, and archaeological objects. The intangible heritage, on the other hand, includes various non-physical aspects of culture such as social values, customs, folklore, social practices, spiritual and aesthetic beliefs, knowledge, and various types of skills, languages, oral traditions, or traditional crafts (Skaldawski, 2017b, p. 11), which are much more difficult than material objects to maintain and protect. 
The importance of cultural heritage is multifaceted and has universal value for us as individuals and as a society. It serves the development of social capital and economic progress, because human creativity can be developed on its foundations (Skaldawski, 2017c, pp. 15-16). It forms the basis of collective identity, allows one to increase a sense of community and belonging, promotes the creation of interpersonal relationships, trust and understanding, and also facilitates cooperation, which occurs as a result of the integration of various local and national, religious, and ethnic communities (Skaldawski, 2017a, p. 7). Therefore, it can be assumed that actions aimed at its preservation as well as a dissemination of knowledge about it are activities for the common good (Skaldawski, 2017a, p. 7). Cultural heritage may also contribute to a stimulation of patriotic feelings and satisfies the need to search for one's own roots (Kobyliński, 2011, p. 22).

Due to the authenticity and integrity of cultural goods, and to the importance of this cultural capital for our identity and the shaping of everyday life (Kobyliński, 2011, p. 22), it is important to protect it and pass it on to future generations, especially as it is an impermanent and non-renewable resource strongly connected with its location (Skaldawski, 2017c, p. 16). Hence cultural institutions designed to preserve and bring society closer to this heritage, and to protect these unique and irreplaceable cultural assets of exceptional and universal value, are being created and developed.

These institutions are libraries, archives, and museums, colloquially referred to as LAM, that is, public and private organizations that are repositories of cultural artefacts as well as functioning as important guardians of heritage and knowledge. The listing of these institutions together as memory institutions (Dupont, 2007, p. 15) stems from the historical closeness between these institutions and the similarity of their missions and activities for the cultural heritage sector as a whole. This is also due to the convergence of their roles in collecting, storing, and sharing artefacts and as evidence of the social, intellectual, artistic, and spiritual achievements of their communities.

The above-mentioned institutions serve in various ways connecting the society with this legacy. As Christian Dupont notes, "libraries, archives and museums are places where we learn about ourselves, the world around us and what lies ahead. They inspire us to create a better future, helping us remember and understand the past" (Dupont, 2007, p. 13).

The special role of LAMs seems to be particularly manifested among immigrant communities, living far away from their country. By cultivating the cultural heritage of their community, preserving the souvenirs that bind it to their home country, they shape and maintain its national identity, a sense of national pride, as well as allowing discovery of cultural diversity and serving international dialogue. 
The role of LAMs for the preservation and promotion of Polish cultural heritage can be illustrated by the example of the Polish Catholic Centre (POK) in Argentina in Martin Coronado, in the area of Greater Buenos Aires.

Argentina, although so distant from Poland, has long enjoyed the reputation of a good country to live among Poles. Already in the nineteenth century, the first settlers began to arrive there. They settled all over the country. Here, in addition to large cities such as Buenos Aires, Cordoba, Mendoza, San Juan, and Santa Fé, clusters of Polish communities can be found from Misiones in the north to Patagonia in the south of the country.

This positive image of Argentina was one of the factors that, after the end of hostilities on the fronts of World War II, persuaded Polish soldiers demobilized in Great Britain, who for political reasons had decided not to return to a Poland dependent on the Soviet Union, chose this country for their resettlement. Over 20 thousand Poles arrived during this time (Wróbel, 1986, p. 347), mainly former soldiers of the 2nd Polish Corps commanded by General Władysław Anders, RAF pilots, and participants of other formations of the Polish Armed Forces in the West along with their families.

As in the case of the first Polish settlers, after the arrival of this group of emigrants various veterans', cultural, and self-help organizations began to be established in response to social demand. They brought former soldiers together and cared for the memory of the struggles they had suffered and the efforts they had expended for a free Poland. The Polish community looked for spiritual care, but also to organize teaching in Polish for children, and to prepare a school library and a collection of books to cultivate the knowledge of the mother tongue (Maciaszkowo, 2019).

Such functions were to be fulfilled by the Polish Catholic Centre, together with a chapel and monastery, the realization of which was begun in 1953 by father Justinian Maciaszek from the congregation of Bernardine Franciscans in Martin Coronado, in the area of Greater Buenos Aires, on a plot of $3197 \mathrm{~m} 2$. It should be added that during the Second World War father Justinian Maciaszek was a prisoner of the labour camps in Kolyma, and then a military chaplain in the army formed in the Soviet Union and in the 2nd Polish Corps.

Works related to the construction of the monastery and chapel were completed in 1958, and then the Polish Catholic Centre was officially created, with extensive pastoral, social, and cultural work being undertaken in Maciaszkowo, as the centre was commonly called in commemoration of its founder and builder (Wróbel, 1986, p. 347-348).

Soon after the opening of the Centre, construction of the school began, which was opened to students in 1962. Due to its coinciding with the anniversary of the baptism of Poland, it was named the Millennium of the Baptism of Poland. The full name of the school is the Saturday School of 
the Millennium of the Baptism of Poland, as classes take place on Saturdays, non-working days in Argentina. 78 children aged 5 to 18 are enrolled in the school. The program included the teaching of religion, Polish, history, geography, singing, and Polish dances (Wróbel, 2007, p. 10). From the very beginning of the school's operation, the educational process carried out there has intentionally been part of the dissemination of knowledge about the history and culture of Poland, its heritage, and its values, among students. In a broader sense, it contributes to shaping civic attitude, respect for the tradition and culture of one's own nation, and respect for other cultures and traditions.

Initially, the social and cultural activities carried out by the Centre focused primarily on supporting the Polish community and nurturing its relations with Poland. Those activities are favoured by numerous Polish diaspora organizations operating at the Centre, such as the Polish Catholic Society (from 1954), boys and girls scout teams, the young scouts group, or the Scouting Friends Circle (from 1961) (Wróbel, 2007, pp. 12-14).

Over time, the scope of the Centre's activity was expanded to include care for former soldiers, lone combatants of World War II, who came to Argentina. With them in mind, in 1982 a Retirement Home was organized in which they could live out the remainder of their days with dignity. The residents were mainly soldiers of the 2nd Polish Corps, as well as participants of other formations of the Polish Armed Forces in the West, residing in Argentina. Efforts to put into practice construction plans for the home had been ongoing since 1976 (Wróbel, 2007, pp. 29-31). They were implemented in 1982, thanks to the gift of a former aviation officer, Zdzisław Skarbek Tłuchowski, and his wife Stefania (Wróbel, 2007, p. 29), as well as the involvement of activists of the Association of Polish Veterans in Argentina and the Union of Poles in Argentina.

Residents of the Retirement Home included, among other high-ranking officers, generals and colonels. In 2009 there were 33 inhabitants in the Home, many of whom were over 90 years old, the oldest being 100 years old (Kaczorowska, 2009). Although some of them are struggling with serious diseases and dementia, there are also those who, despite their nearly 100 years, actively participate in various jubilee celebrations commemorating the fights for Tobruk, the battle of Monte Cassino, or celebrating the 100th anniversary of the Independence of Poland.

Documents and souvenirs of many military charges were sent to the Centre, enriching it with extraordinary evidence showing the fighting of Polish soldiers and their contribution to the end of World War II, and thus obliging the Centre to secure the Polish heritage entrusted to the monks by the former soldiers who lived in Argentina.

Over time, as a result of the strenuous efforts and enormous commitment of the Centre (POK), whose agencies are libraries, museum, and ar- 
chive, their activities were not limited to the role of a safe depository of the materials entrusted to them. In addition to the storage and protection of these materials, they have become a tool for disseminating knowledge about the history of Poland related to World War II and also to older events. An illustration of such activities commemorating the history of the native country is the celebration of various anniversaries important for Poles, e.g. the anniversary of Poland regaining independence (November 11), the Constitution of May 3, 1791, the Battle of Warsaw ${ }^{1}$, the 500th anniversary of the birth of Copernicus, the 300th anniversary of the relief of Vienna $^{2}$, or the 60 th anniversary of the outbreak of the Warsaw Uprising ${ }^{3}$. Plaques commemorating these events are embedded in the base of the flagpole located in the square in front of the chapel (Wróbel, 2007, pp. 2426), thanks to which they have become an important source of knowledge and contribute to strengthening the value of this heritage. And this, in turn, contributes to the development of the awareness and national identity of the Argentine Polish community, integrates it around similar values, strengthens patriotic attitudes and spiritual experiences, and impacts the sense of pride in having Polish roots.

Undoubtedly, the construction of the monument of the Polish Pope John Paul II in 1999 at the Centre (POK), and, after his death in 2005, the renaming of the street from Becquer to Juan Pablo II, have had a big impact on the Polish people living in Argentina (Wróbel, 1986b).

So, in addition to the painstaking work of the monks, and also as a result of the "spontaneous transmission of cultural patrimony from generation to generation" (Lubaś, 2017, p. 19), the Polish Catholic Centre affects the social development of the local population. Often after services accompanying church or national celebrations, joint dinners are organized at the Centre, which provides a great opportunity to integrate and strengthen the community. Often these meetings are accompanied by music, dance and recital performances for children and youth groups, as well as for older members of the Polish community. They provide a chance to reminisce, to invoke Polish songs, patriotic songs, or native literature, e.g. works by Juliusz Słowacki or Adam Mickiewicz. Not only people living near the Centre, but also those coming from distant places participate in them. Given the deteriorating knowledge of Polish among young Argentineans of Polish descent, this is a great opportunity to listen to songs in Polish and learn Polish folk dances performed in regional costumes. It is

\footnotetext{
${ }^{1}$ Fought on August 13-25, 1920 during the Polish-Bolshevik war, which was decisive in maintaining Poland's independence and forestalled Soviet plans to spread communism to Western Europe.

${ }^{2}$ Victory of King Jan Sobieski near Vienna in 1683, which stopped the invasion of Turkish troops upon Europe.

${ }^{3}$ The Warsaw Uprising broke out on August 1, 1944, lasting 63 days. It was directed against the German occupier.
} 
important that people associated with the Centre join in the preparation of the sets and costumes, and that the texts used come from the school library operating at the Centre (Wróbel, 1986, p. 349).

\section{LIBRARIES, ARCHIVE, AND MUSEUM AT THE POLISH CATHOLIC CENTRE}

\section{LIBRARIES}

The implementation of the intentions outlined in the creation of the Centre related to the preservation of Polish culture, history, and language was made possible thanks to the libraries, whose organization was already begun by father Justynian Maciaszek. Even then he was aware of the great importance of libraries for the preservation and maintenance of Polish cultural heritage. As a result of the efforts of monks, clergy and laymen from Argentina and the United States, the collections of books increased rapidly. Two separate book collections were created: monastery and parish, which intentionally constituted "[...] treasures of the Polish spirit and culture in exile. At the Polish church, we wanted to create a spiritual cultural institution and a strong linguistic bond with the nation through the printed word. And culture is universal in nature, hence the multilingualism of the library, which testifies to familiarity with languages and various interests" (Smoleń, 1985).

The monastery library has a scientific profile. It contains about 11,000 items, which include publications on issues of religion and history, Polish immigrants in South America and in Argentina itself, congregations of Franciscans, John Paul II, and a rich collection of magazines.

The collections are sorted according to 7 sections. These are:

* Handbooks, Prayer Books, Sermons, Catechesis, Meditations, Biographies;

* The Holy Bible, Church Teachings, Comments, Lives of the Saints;

* History, Diaries, Memories, Philosophy, Reports;

* Fiction and Literature;

* Miscellanea dedicated to, among other things, librarianship, art, geography, and including language textbooks, albums, and guides;

* Journals;

* Encyclopaedias and Dictionaries.

From the point of view of the Polish heritage related to World War II, the sections on History, Diaries, Memoirs, Philosophy and Reports are of particular interest, containing about 1600 volumes, and Periodicals. In this two sections, a large part of the collections consist of books and periodicals related to the war efforts on the fronts of World War II conducted by the Polish Army in the East, especially the 2nd Polish Corps formed on 
its basis and commanded by General Władysław Anders. The 2nd Polish Corps included, among others, The 3rd Carpathian Rifle Division (3DSK), which as the Carpathian Rifle Brigade (Brygada Strzelców Karpackich BSK), was created on 4 December, 1940, in Syria, which was then a French mandate territory ${ }^{4}$.

It is necessary to emphasize that in the ranks of 3DSK and its earlier formations (Carpathian Rifle Brigade - (BSK) and Independent Carpathian Rifle Brigade (Samodzielna Brygada Strzelców Karpackich - SBSK) "[...] there was a real elite of society [...] and there was probably no army in which there was such a large percentage of artists, writers and painters, poets and scholars, intellectuals, engineers, doctors" (Załęczny, 2017, p. 188). These would have included Marian Hemar (who before the war, together with the poet Julian Tuwim, wrote texts, among others, for the very successful theatres "Qui pro Quo" and "Cyrulik of Warsaw"), Paweł Prokopieni (who sang together with the famous tenor Jan Kiepura) and Stanisław Młodożeniec (co-creator of futurism in Polish poetry) (Zaprutko-Janicka, 2012). The 3rd Carpathian Rifle Division (3DSK) and Carpathians "[...] could therefore create - and did create - its own literature with characteristic motifs and eastern and desert moods, theatre and valuable, non-subsidized soldier's press" (Młotek, 1985, p. 44).

Particularly valuable are the works collected in the section History, Diaries, Memories, and Philosophy, which include reportages popularized by the publishing houses of the 2nd Polish Corps (including 3DSK). For example, the publishing house "W Drodze" ("On the Road") published a total of 42 titles (Czarnik, 2012, p. 101), including anthology collections of soldiers' poetry, Poezja karpacka (Carpathian Poetry); books printed as part of the "Biblioteka Orła Białego" ("White Eagle Library") publishing series which were used to disseminate contemporary literature to soldiers (Czarnik, 2012, p. 228); works of Polish writers of the 19th and early 20th centuries; books published by the Polish YMCA at the 2nd Polish Corps in Rome or by the Polish Publishing House, including works of Melchior Wańkowicz, Zygmunt Bohusz-Szyszko, Zofia Kossak, as well as memoires of the commanders of the units included in the 2nd Polish Corps concerning the period of fighting in Iran, North Africa, Italy, at Monte Cassino. There are also schoolbooks and readings published by the Office of Education and School Affairs in Jerusalem, renamed in 1943 the Delegation of the Ministry of Religious Denominations and Public Enlightenment in Jerusalem (Czarnik, 2012, p. 101).

${ }^{4}$ Polish soldiers of the Carpathian Rifle Brigade, were then transformed into the Independent Carpathian Rifle Brigade and organized on the basis of the 3rd Carpathian Rifle Division at the beginning of May 1942. The unit was called the Carpathian, and the soldiers Carpathians, because almost all of them had had to pass through the Carpathians to join it. 
The periodicals section has over 414 titles, mainly in Polish, from the Second World War, published in the Middle East and Italy and also in England and France, as well as magazines published in the United States of America by Polish diaspora organizations before and after the Second World War. You can find "Głos Lwowian" ("The Voice of Lviv residents"), and "Głos Polski" ("The Polish Voice") of the Union of Poles in Argentina. Selected contemporary Polish magazines are also collected here.

The number of magazines published along the route of the Polish Army in the East, especially the 2nd Polish Corps, confirms the opinion held among foreigners coming into contact with Polish units on the fronts of World War II that "[...] where there is a Pole - there is a newspaper" (Załęczny, 2017, p. 183). "Publishing Polish newspapers was a way of satisfying the need for the Polish written word that was felt by soldiers thrown by fate far away from their country, longing for families and homeland" (Załęczny, 2017, p. 183); they were also a source of information on activities on the fronts (Załęczny, 2017, p. 184). They presented a military chronicle, a review of political events, showed military life, news from the front, news from the home country, a literary section or a phrasebook in English along with a Polish-English dictionary.

A large group consists of magazines published by SBSK, or later by 3DSK, which was part of the 2nd Polish Corps. The dominance of magazines published by this formation is not surprising, because, as mentioned earlier, these military units included the elite of Polish society, educated people who turned out to be very active, making the Brigade/Division not only an efficient military unit, but also an oasis of flourishing Polish culture (Krząstek, 2010, p. 22). It should be remembered that Independent Carpathian Rifle Brigade published as many as 19 magazine titles at different times and at different intervals (Załęczny, 2017, p. 183). Unfortunately, the titles collected in the library are rarely complete, more often they are single issues.

The titles in the library include those that were from the official press bodies of the SBSK: "Ku Wolnej Polsce" ("Towards Free Poland") and "Nasze Drogi" ("Our Roads").

"Ku Wolnej Polsce" was a daily magazine of the Carpathian Rifle Brigade (BSK), published from 1940, under which 392 issues were printed (Krząstek, 2010, p. 22) with self-contained supplements appearing from 1941: "Dodatek Tygodniowy" ("Weekly Supplement"), "Polska" ("Poland"), and "Nasz Tygodnik" ("Our Weekly") (Czarnik, 2012, p. 459). The newspaper "Ku Wolnej Polsce" enjoyed enormous popularity among soldiers, it was read "from cover to cover" and passed on from hand to hand (Załęczny, 2017, p. 186). It was a medium of enormous motivational power, thanks to the publication of texts in its pages, including literary texts, emphasizing the heroism and commitment of soldiers fighting in the 
ranks of the ICRF (Załęczny, 2017, p. 183). The biweekly "Nasze Drogi” was published from February to December 1941 in Tel-Aviv (Załęczny, 2017, p. 185). According to Oskar S. Czarnik, it was "[...] the leading Polish opinion-forming publishing house in the Middle East, being at a high substantive and editorial level" (Czarnik, 2012, p. 63).

Other titles in the Centre's libraries include:

- "Orzeł Biały" ("White Eagle"), published since 1941 by the Fighting Poland in the East/Military Office of Propaganda and Education of the Polish Armed Forces in the USSR, and including post-war numbers and additions to "Orzeł Biały": "Pani w domu i na świecie" ("The Lady at Home and in the World"), "Pokrzywy" ("Nettle");

- "Na Szlaku Kresowej" ("On Kresowa's Trail”), a magazine published by the Department of Culture and Press of the 5th Kresowa Infantry Division in Italy;

- "Nasz Przyjaciel. Dwutygodnik Uchodźstwa Polskiego w Afryce, wydawany w Nairobi" ("Our Friend. Biweekly of Polish Refugees in Africa, published in Nairobi"), which was a continuation of the weekly with the same title published in Iran; also, "Polonia", a periodical published in Nairobi in 1956-1959;

- "Poradnik dla pracowników świetlic żołnierskich" ("Guide for employees of soldiers' clubs"), edited in 1943 by +YMCA;

- "Ochotniczka. Pismo Pomocniczej Służby Kobiet" ("Volunteer. Women's Auxiliary Service Journal"), a monthly published in 1943-1944 in Palestine, Egypt, and Italy;

- "Skaut" ("Scout"), a monthly published from 1942 by the Polish Scouting Association in the East;

- "Wiadomości Wojskowe 2 Korpusu" ("Military News of the 2nd Corps") published in Italy and then in England by the Main Board of the Society of Military Sciences;

- "Uwaga nadchodzi. Miesięcznik artylerii przeciwlotniczej" ("Attention, air-raid. Anti-aircraft artillery monthly", edited in Italy in 1945-1946;

- "Parada" ("Parade"), an illustrated biweekly of the Polish Army in the East, published from 1943;

- "Kronika" ("Chronicle"), a monthly printed from 1946 in Rome by the Department of Culture and Press of the 2nd Corps;

- "Myśl Polska na Wschodzie" ("Polish Thought in the East"), a quarterly published from 1946 in Jerusalem by the Stronnictwo Narodowe (National Party) in the East.

In addition to the monastery library, there is also an educational parish library. Its mission is to provide relatively full and current knowledge about Poland and Polish contemporary literature. Its size is about 3,650 volumes in the fields of literature, history, fiction and religion. These are primarily books in Polish. Books in other languages constitute a very small 
percentage. The library contains, among others, textbooks for learning foreign languages, professional education textbooks, dictionaries, encyclopaedias, fiction, albums, and guides. As noted by father Piotr Kotyła, a librarian for many years at the Centre, although publications collected for years on such subjects as Poland's independence are already of a historical nature following the changes made in Poland after 1989, nevertheless these activities for freedom in Poland cannot be forgotten or deleted from our memory. "They must remain in our consciousness and in our hearts" (Kotyła, 2001). The book collection is constantly being updated with new publications from Poland and abroad. The library is open every Sunday (Wróbel, 1986, p. 350).

With the creation of the school in 1962, it was necessary to organize a library whose collections would support the didactic and educational activities carried out by this institution, mainly in relation to the study of its mother subjects: language, literature and history. The library's collection includes textbooks, schoolbooks, and fiction, especially for children and young people. In 1985, the size of this library was about 1,000 volumes (Smolen, 1985). Currently, the collection of the school library has about 1,500 volumes.

\section{ARCHIVE}

With the creation of the monastery and the Polish Catholic Centre, beside gathering books, archival materials were also being collected, dictated by the need to save the history of Poles arriving in Argentina from oblivion. The core of the collection was formed from documents relating to the activities of the founders of the monastery and the Centre the fathers Justinian Maciaszek and Andrzej Smolen - as well as from those pertaining to the Bernardine Franciscan monastery itself. They form a group of archives of religious activities as broadly understood. There are documents about the Centre, the clergy associated with it, chronicles of the monastery, pastoral work, as well as sermons and lectures given by individual priests. With time, after the location of the Rectorate of the Polish Catholic Mission (Polska Misja Katolicka - PMK) at POK in Maciaszkowo in 1971 (Wróbel, 2007, p. 15), that covers the entire territory of Argentina, and which also cultivates Polish traditions, documents regarding the Mission and its activities also began to be gathered in the archive.

One extensive group of archival materials consists of materials about the Polish community in Argentina, its institutions and individuals, as well as soldiers who came there after the Second World War. These contain both collections brought to Argentina and those produced in the country. You can find there documents regarding the Friends of Scouts, the Retirement Home, the Saturday School of the Millennium of the Baptism of Poland in Martin Coronado, or the Legionnaires' Circle and the 
Polish Military Organization in Argentina. The legacies of people who came to Argentina and were associated with the Polish Catholic Centre are rich and valuable. One may mention here by way of example archives regarding soldiers and officers fighting in the 2nd Polish Corps, in its units such as 3DSK or the 5th Armoured Division, such as Józef Filipowicz, an aviator fighting in September 1939, Rudolf Leroch-Orlot, an officer of the 1st Legion Polish Brigade and long-time president of the Legionnaires' Circle and the POW ${ }^{5}$, Lieutenant Zdzisław Skarbek Tłuchowski, General Jerzy Aleksander Zawisza, president of the Union of Poles in Argentina and a distinguished figure for Polonia and for veterans (he was one of the organizers of the Retirement Home), and Włodzimierz Toczyłowski. Some of the archives were used to present these men in the Dr Antoni Sołowiej Polish Army Museum.

A separate group of documents, included in the POK archive, consists of the private collection of father Herkulan Wróbel, a long-time employee and Rector of Polish Catholic Mission who also looked after the entire legacy collection located in Maciaszkowo. This legacy includes materials on the activities of Polish priests, nuns, and monks who have been working in Argentina since the nineteenth century, as well as relating to the imprisonment of Polish clergy in German concentration camps during World War II.

A complementary documentation file consists of film and sound recordings (approx. 250 cassette tapes), and a collection of several hundred loose photographs.

In 2008, as a result of establishing cooperation between the Polish Catholic Mission and the Central Directorate of State Archives in Poland, the accumulated documents were organized and their records drawn up. These resources have been grouped within 24 subject groups, including collections in the archive. The entire archival resource includes over 1000 files occupying approximately 26 linear meters (Wróbel, 2007a).

One of the people whose legacy is held in the archive and whose souvenirs are exhibited in the museum is lieutenant Jan Gilowski (1904-1991) (Zybert \& Maruszak, 2018). It is worth mentioning him for several reasons: his pictures - 22 painted on canvas taken from military tents - decorate the Museum's halls, and his watercolours are housed in the files of the archive. Jan Gilowski, a figure unknown in the history of art, but vividly associated with the entire current of spiritual creativity of the Carpathians. With the Carpathian soldiers he went all the way from Homs in Syria to the victorious end of the war, which found him in Italy. On the route of the war, under difficult spartan conditions, he painted 94 watercolours

${ }^{5}$ Polska Organizacja Wojskowa (POW) - Polish Military Organization - a secret military organization operating in the years 1914-1921. 
(92 measuring $13.5 \times 20 \mathrm{~cm}$ and two $20 \times 28 \mathrm{~cm}$ ). Like other writers, poets, painters, musicians, and actors creating within the conditions of military service, he documented unforgettable moments of the struggles of soldiers with their own weaknesses, longing for loved ones, fighting the enemy, for example in defending the Tobruk fortress (1941). He showed the conditions of life in the war, work on fortifications, mining in the area, and the everyday life of civilians. As valuable as the watercolours themselves are the notes drawn up on their reverse, such as a fragment of a poem by a colleague from the same unit, the well-recognized poet Tadeusz Sowicki, whose works were published at that time in Jerusalem (Zybert \& Maruszak, 2018). All of which confirms that the Carpathian soldier "[...] carried books in his backpack, discussed, wrote, absorbed knowledge, looked at monuments, learned languages, and established relations with strangers on behalf of the nation" (Załęczny, 2017, pp. 178-179).

\section{MUSEUM}

The idea of creating a military museum was born out of the close relations between the Maciaszkowo monks and the soldiers who arrived in Argentina after the war, especially those who settled in the area of Greater Buenos Aires. It was opened and consecrated by Cardinal Władysław Rubin in 1968 and for many years operated as a Hall of Memory to which veterans or their families could transfer their military memorabilia. However, it was not until 1984, on the initiative of Dr Antoni Sołowiej, also a soldier of the 2nd Polish Corps and a distinguished Polish diaspora activist, that actions were taken to transform this Hall so that it could better perform its function as an exhibition space, and so that its collections could be used within the didactic and educational activities of the school in which it was located. At that time, the museum was also named after Dr Sołowiej. From that moment, the facility has been called the Lieutenant Doctor Antoni Sołowiej Polish Army Museum, Museo del Ejército Polaco Dr Antonio Solowiej en Martin Coronado ${ }^{6}$.

Thanks to the financial support of the Senate of the Republic of Poland and the Association "Wspólnota Polska" ("Polish Community"), in 2017 the Museum was renovated and its exhibition area increased. Once again, the museum was officially reopened. At present, it is one of the largest and richest Polish military museums when it comes to collections outside of Poland. "The renovation of the Museum made it possible to professionally secure and classify the exhibits located in it, opening the door wide for compatriots and everyone interested in the history of the 20th century. Undoubtedly, due to the impact of the authentic objects that it exhibits, it

${ }^{6}$ A film presenting the Museum of the Polish Army named after Dr A. Sołowiej is available on the Internet https://www.youtube.com/watch?v=ga8i_haalok 
is a valuable reference point, and perhaps a complement to the history of World War II" (Maruszak \& Zybert, 2018, p. 9).

The museum premises consist of four exhibition halls, with a permanent exhibition presenting priceless souvenirs of Polish soldiers fighting in the Polish Armed Forces, including personal items brought from camps in Russia and Germany. The Museum collected original soldiers' uniforms for both ordinary soldiers and officers, items of clothing (berets, four-cornered caps, belts, shirts, pants, jackets, shoes), parts of soldiers' equipment (masks, kit bags, mess-boxes), identity tags, glasses, cigarette cases, prayer books, gorgets, vestments of military chaplains and stoles. There is a large collection of Polish as well as British and Italian decorations. Some of the decorations have ID cards, numerous photos and documents belonging to, among others, General Jerzy Aleksander Zawisza, Lieutenant Zdzisław Skarbek-Tłuchowski, Włodzimierz Toczyłowski, Stefan Zychowicz, Józef Filipowicz, Brigadier General Michał Rzepczyński, Captain Antoni Żebrowski, Colonel Rudolf Leroch-Orlot, Lieutenant Dr Antoni Sołowiej, Colonel Aleksander Florkowski, and the nearly hundred-year-old Major Dąbrowski, who fought at Monte Cassino.

In one of the rooms there are also cots which accompanied the soldiers along the trail and together with them reached Argentina, along with sleeping bags, maps, boards and parts of ammunition.

On the walls of the museum halls are hung hand-made maps showing the route of the troops' journeys, as well as paintings depicting the wartime route of the 3rd Carpathian Rifle Division and other units included in the 2nd Polish Corps, painted on canvas cut from soldiers' tents. Their author is Lieutenant Jan Gilowski.

The Museum also has a section devoted to contemporary affairs: in what is called the Argentine Corner, documents have been gathered showing the participation of Argentineans of Polish descent in the war over the Malvinas-Falkland Islands in 1982 in the South Atlantic. Among other artefacts, there are an anchor, an engine, and torpedo fragments that caused the sinking of the Argentine battle cruiser General Belgrano. Of course, the Museum could not be without souvenirs of the founders of the monastery and the Centre, fathers Justinian Maciaszek and Andrzej Smoleń. An extremely valuable exhibit, presented in the monastery building, is the original white and red banner from the Warsaw Uprising in 1944, owned by the women's scouting group in Matin Coronado, named after the "Zośka" Battalion.

Thanks to the Museum's activity, these valuable and unique items, now eagerly viewed by students of this school as well as of other Argentine schools and by guests from Poland and Argentina, cultivate Polishness and the memory of Polish soldiers, and are a huge contribution to the care and dissemination of the Polish cultural heritage and its protection from 
oblivion. By documenting, popularizing and promoting the history of Poland, reaching out to inspirational examples of Polish achievements, the Museum contributes to educating and crystallizing modern patriotic sensitivity, to stimulating creative attitudes and shaping citizens' awareness of their traditions and openness to the world.

\section{CONCLUSION}

Although the main activity of both the Polish Catholic Centre and Polish Catholic Mission to protect the Polish cultural heritage on the territory of Argentina is concentrated in Martin Coronado and in the agencies operating there, these institutions also take care of other Polish clusters more dispersed and distant from Buenos Aires. With the arrival of the Bernardine Franciscan monks from Poland in 1966, spiritual and socio-cultural activities were offered to the Polish community in Greater Buenos Aires, including San Jose, Llavallo, Merlo, San Justo, and also in Rosario or Córdoba (Wróbel, 1986, p. 353). As Father Herkulan Wróbel notes, it is this dispersion that increases the importance of the Polish Catholic Centre, which attracts members of the Polish diaspora not only for religious reasons, but also out of the need to maintain connection with other Poles, as well as to strengthen their identity (Wróbel, 1987, p. 353).

Furthermore, in 2005 the Polish Catholic Mission took over the care of compatriots living in the province of Misiones, in Apostoles, Azara, and Puerto Libertad, which meant that activities for the benefit of Polish cultural heritage were also intensified there (Maciaszkowo, 2019). It is worth mentioning that it was in Misiones, on the border between Argentina, Paraguay and Brazil, that the first groups of Poles settled, and thanks to the activity of the monks from Martin Coronado, the cemetery of the first Polish settlers in Azara was renovated. It is a testimony to Polish emigration and also a commemoration of the Polish contribution to the development of Argentina. That Poles have made a significant contribution to this progress was confirmed by the establishment of Polish Settler Day in 1995 by the Argentine authorities (Spanish: "Día del Colono Polaco"), which is celebrated on June 8 (Maciaszkowo, 2019).

Very rich activities for the benefit of Polish cultural heritage are also carried out in a town near Puerto Libertad which the settlers have called Wanda. There is a mine of precious stones there, rock crystals, amethysts and agates, whose deposits were discovered by Poles. In addition to a Polish school and church called Polish Częstochowa, there is a thriving Museum of Polish Emigration, dedicated to the Poles who founded this town. There are exhibits brought by Polish settlers: books, service books, archives, photos, agricultural tools, as well as a light four-wheeled horse 
cart, used in farm work, called carros polacos, which due to its previously unknown construction methods and lightness became very useful and widely used by people of different nationalities living in this area.

In conclusion, the LAM at the Polish Catholic Centre in Martin Coronado and in places cared for by the Polish Catholic Mission has been an excellent advocate for activities benefiting the Polish cultural heritage outside of Poland. It protects, cares for, disseminates and educates about this heritage, preserving the identity of the Polish community in the country, but also enriching the world's cultural heritage. It is an important testimony to history and plays an important role in shaping and also in reconstructing local and national identity. This LAM also contributes to a greater interest in the fate of a distant homeland, its history and culture, and also in relation to the present. It should be remembered, furthermore, that identity is not given once and for all, to be ever unchanging (Fortuna-Marek \& Stępnik, 2017, p. 26): it is necessary to constantly take steps to protect it. While it is unfortunately the case that fewer and fewer young people generally are speaking Polish, thanks to the activities of the Polish Catholic Centre they have nevertheless remained aware of their Polish roots.

\section{BIBLIOGRAPHY}

Convention for the Protection of the World Cultural and Natural Heritage, Paris 1972 (1972). In: Vademecum konserwatora zabytków. Międzynarodowe normy ochrony dziedzictwa kultury/edycja 2015/. (2015). Warszawa: Polski Komitet Narodowy ICOMOS, pp. 45-55.

Council of Europe Framework Convention on the Value of Cultural Heritage for Society, Faro 2005. In: Vademecum konserwatora zabytków. Międzynarodowe normy ochrony dziedzictwa kultury/edycja 2015/. (2015). Warszawa: Polski Komitet Narodowy ICOMOS, pp. 163-170.

Czarnik, Oskar Stanisław (2012). W drodze do utraconej Itaki. Prasa, ksiażki i czytelnictwo na szlaku Samodzielnej Brygady Strzelców Karpackich (1940-1942) oraz Armii Polskiej na Wschodzie i 2.Korpusu (1941-1946). Warszawa: Biblioteka Narodowa.

Dupont, Christian (2007): Libraries, Archives, and Museums in the Twenty-First Century: Intersecting Missions, Converging Futures? A Journal of Rare Books, Manuscripts, and Cultural Heritage. [online], vol. 8 no. 1, pp. 13-19. [accessed on: 19.07.2019]. Available on: <https://rbm.acrl.org/index.php/rbm/article/view/271>, doi: https://doi.org/10.5860. rbm.8.1.271

Fortuna-Marek, Anna; Stępnik, Konrad (2017). Komponenty postaw Polaków wobec dziedzictwa kulturowego. In: Dziedzictwo kulturowe w badaniach. Polacy wobec dziedzictwa Raport z badań społecznych. Warszawa: Narodowy Instytut Dziedzictwa; Kraków: Instytut Socjologii UJ, 2017, pp. 22-44.

Kaczorowska, Teresa (2009). Ostatni Mohikanie z Maciaszkowa. Reportaż z Argentyny. Strona autorska Teresy Kaczorowskiej. [online], [accessed on: 19.07.2019]. Available on: <http:// www.kaczorowska.com/index.php?numer=8\&nr=1\&p=15>.

Kobyliński, Zbigniew (2011). Czym jest, komu jest potrzebne i do kogo należy dziedzictwo kulturowe? Mazowsze. Studia Regionalne vol.7 pp. 22-27. 
Kotyła, Piotr (2001). Katalog biblioteki podręcznej. Polskiego Ośrodka Katolickiego Ojców Franciszkanów w Martin Coronado. [online]. Polonijna Biblioteka Cyfrowa [accessed on: 19.07.2019]. Available on: <http://www.pbc.uw.edu.pl/6508/1/Katalog_Podr.pdf>.

Krząstek, Tadeusz (2010). Tobruk. Pamiątki chwaty Karpatczyków. Warszawa: Vipart.

Lubaś, Marcin (2017). Teoria dziedzictwa kulturowego w naukach społecznych. In: Dziedzictwo kulturowe w badaniach. Polacy wobec dziedzictwa. Raport z badań społecznych. Warszawa: Narodowy Instytut Dziedzictwa, Kraków: Instytut Socjologii UJ, 2017 pp.17-19

Maciaszkowo-Nasz Ośrodek (2019). [online], [accessed on: 19.07.2019]. Available on: <https:// maciaszkowo.pl>.

Maruszak, Elżbieta; Zybert, Elżbieta Barbara (2018). Polski Ośrodek Katolicki w Martin Coronado kustoszem pamięci o żołnierzach na tułaczym szlaku XX wieku. Cenne, bezcenne, utracone [online], 2018, no. 3 (92) - 4 (93) 11 p. [accessed on: 19.07.2019]. Available on: <http://cennebezcenne.pl/archiwum/nr-392-493-2018/>.

Młotek, Mieczysław (1985). Krótki zarys historii Brygady Strzelców Karpackich. Lenght: Zarząd Główny Związku Tobrukczyków.

Polski Ośrodek Katolicki w Martin Coronado (br). [online]. Polonijna Biblioteka Cyfrowa [accessed on: 19.07.2019]. Available on: <http://www.pbc.uw.edu.pl/6500/1/Coronado_historia.pdf $>$.

Skaldawski, Bartosz (2017b). Problematyka definicji dziedzictwa. In: Dziedzictwo kulturowe w badaniach. Polacy wobec dziedzictwa Raport z badań społecznych. Warszawa: Narodowy Instytut Dziedzictwa, Kraków: Instytut Socjologii UJ, pp. 9-12.

Skaldawski, Bartosz (2017a) Introduction. In: Dziedzictwo kulturowe w badaniach. Polacy wobec dziedzictwa Raport z badań społecznych. Warszawa: Narodowy Instytut Dziedzictwa, Kraków: Instytut Socjologii UJ, 2017 pp. 7-8.

Skaldawski, Bartosz (2017c). Działania na rzecz zachowania dziedzictwa jako istotny element polityki kulturalnej państwa. In: Dziedzictwo kulturowe w badaniach. Polacy wobec dziedzictwa. Raport z badań społecznych. Warszawa: Narodowy Instytut Dziedzictwa, Kraków: Instytut Socjologii UJ, pp.13-17.

Smoleń, Andrzej (1985). Katalog biblioteki klasztornej oo. franciszkanów w Martin Coronado. Wstęp. [online]. Polonijna Biblioteka Cyfrowa [accessed on: 19.07.2019] Available on: $<$ katalog biblioteki klasztornej oo. franciszkanów w Martin Coronado. www.pbc.uw. edu.pl/6627/1/Katalog_Dzial_G.pdf>.

Wróbel, Herkulan (oem) (1986). Działalność kulturalna polskiego ośrodka katolickiego oo. franciszkanów-bernardynów w Martin Coronado (Argentyna). Studia Polonijne [online], T. 10, pp. 347-355 [accessed on: 19.07.2019]. Available on: <czasopisma.tnkul.pl/ index.php/sp/article/download/5742/5855>.

Wróbel, Herkulan (oem) (2019). Generat Jerzy Aleksander Zawisza. [online]. Polonijna Biblioteka Cyfrowa [accessed on: 19.07.2019], Available on: <http://www.pbc.uw.edu. pl/6498/1/Aleksander_Zawisza.pdf>.

Wróbel, Herkulan (oem) (1986b). Polski Ośrodek Katolicki w Martin Coronado. [online]. Polonijna Biblioteka Cyfrowa [accessed on: 19.07.2019]. Available on: <http://www.pbc. uw.edu.pl/6501/1/Coronado_inwentarz.pdf>.

Wróbel, Herkulan (oem) (2007a). Polski Ośrodek Katolicki w Martin Coronado. Archiwum oo franciszkanów. [online]. Polonijna Biblioteka Cyfrowa [accessed on: 19.07.2019]. Available on: <http://www.pbc.uw.edu.pl/view/divisions/Archiwum=5FCoronado.html $>$.

Wróbel, Herkulan (oem) (2007). 50 lat Polskiego Ośrodka Katolickiego oo. bernardynów (franciszkanów) w Martin Coronado 1957-2007. Buenos Aires. 
Załęczny, Jolanta (2017). Życie kulturalne w Samodzielnej Brygadzie Strzelców Karpackich. Niepodległość i Pamięć, no. 24/2 (58), pp. 175-202.

Zaprutko-Janicka, Aleksandra (2012). Co Polacy broniący Tobruku robili w czasie wolnym? Ciekawostki historyczne pl. [online]. Luty [accessed on: 22.07.2019]. Available on: https:// ciekawostkihistoryczne.pl/.../co-polacy-broniacy-tobruku-robili-w-czasie-woln... artykut.

Zybert, Elżbieta Barbara; Maruszak, Elżbieta (2018). ... Do Polski idziemy przez cały świat.... Karpatczycy na obrazach Jana Gilowskiego. Warszawa: Oficyna Wydawnicza Aspra-JR. 